Article

\title{
Political Leadership as Meta-Governance in Sustainability Transitions: A Case Study Analysis of Meta-Governance in the Case of the Dutch National Agreement on Climate
}

\author{
Menno Ottens and Jurian Edelenbos* \\ Department of Public Administration, Erasmus School of Social and Behavioural Sciences, \\ Erasmus University Rotterdam, 3062 PA Rotterdam, The Netherlands; menno.ottens@live.nl \\ * Correspondence: edelenbos@essb.eur.nl; Tel.: +31-10-4081-916
}

Received: 28 September 2018; Accepted: 18 December 2018; Published: 25 December 2018

\begin{abstract}
Sustainability transitions are of an inherently political nature. In particular, discussions on climate policy are dominated by national and international politics. Furthermore, sustainability transitions involve network governance in which both private, public, and societal actors are involved. These governance processes call for closely scrutinizing their performance in terms of democratic legitimacy. To study and assess the democratic quality of governance processes regarding climate policy, this article focuses on the role of political leadership, conceptualized as political meta-governance, in enhancing the democratic legitimacy in the field of sustainability transitions. In doing so, it examines the case of the Dutch National Agreement on Climate ("Nationaal Klimaatakkoord"). The findings of this study underline the theoretical assumption that governments seek to use network governance to address climate change and develop policies. Seeking to address the application of political meta-governance, this study finds that political leaders struggle to bring about a fully-fledged, deliberative, and integrative meta-governance approach. However, disparate meta-governance strategies are reported. Although democratic legitimacy concerning the Dutch Agreement on Climate in terms of accountability can be regarded as high, values concerning voice (inclusiveness) and due deliberation (transparency) score comparatively low. As such, this study further justifies the close attention governance scholars and practitioners pay to the democratic values at stake when governing through governance networks.
\end{abstract}

Keywords: meta-governance; sustainability transitions; interactive governance; network governance; democratic legitimacy; climate; climate governance; accountability; political leadership

\section{Introduction}

As has been heralded with several national and international agreements concerning climate change, a global momentum appears to have come about to further accelerate the transition towards more sustainable societies. Generally, it is acknowledged that sustainability transitions, being socio-technical processes of transformative change, demand the close collaboration between interdependent actors that interact in order to make decisions [1-5]. Sustainability transitions thus provide a particular instance in which new modes of societal steering are likely to emerge $[5,6]$. The presence of hybrid forms of interactive decision-making and network governance, in which several actors interact and exchange ideas, is widely recognized, and even considered a core characteristic of sustainability transitions [7]. Although exact definitions may differ among scholars [8], related modes of governance indeed assume the emergence of networks or arrangements of interdependent 
societal, private and/or public entities that operate autonomously, surround a policy problem or (public) service, and interact in order to exchange resources and make decisions together [9-13].

These patterns of interaction give rise to an arrangement of actors concerned with a particular problem or service, which engages in a governance process based on interaction $[12,14,15]$. This constellation of operational autonomous, but interdependent actors is often referred to as a "governance network" [10].

Despite the relatively autonomous character of the operations of these networks, "sustainability transitions are inherently of a political nature, simultaneously reflecting, reinforcing and transforming existing institutional and governance arrangements, $(\ldots$ ) relationships between different actors and the unequal distribution of power within and among social groups and interests" [16]. Although government thus is not the sole actor, but rather an agent of one of the many involved interests, its role in sustainability transitions remains significant. Hendriks, here, argues that conventional and emergent forms of governance "co-exist" [17]. Although it is acknowledged that a multi-stakeholder governance approach is favorable, governmental actors retain to have a strong position in organizing and eventually steering these processes of interactive governance [18-21]. Christopoulos et al. [1] offer an example of a role for state-level actors in coordinating governance activities concerning Energy Efficiency policies (EE). In a similar vein, Head [22] calls for pluralistic, multi-stakeholder approaches orchestrated by government regarding effective climate adaptation measures in Australia. Avelino et al. [23] warn that the remaining importance of politics may cause novelties and innovations to be "captured" by vested interests. Thus, whether positive or potentially negative, power and politics in sustainability transitions are ambiguous and, indeed, continue to call for close examination [24].

Therefore, sustainability transitions take place in a governance network context [17]. A persistent dilemma underlying the emergence of governance networks is their potential lack of legitimacy, because the primacy of politics might get challenged, and decisions are taken based on horizontal relations and mutual accountability [25-27]. In this situation no-one can feel accountability, which in turn hampers the democratic legitimacy of (political) decision-making. We still know little about how legitimacy is safeguarded in governance processes, which is particularly ambiguous in sustainability transitions $[28,29]$. Consequently, how democratic legitimacy in governance networks in sustainability transitions is safeguarded is an important normative and empirical question [30].

In this article, we set out to further examine the question of democratic legitimacy in governance networks in the context of sustainability transitions. We pay special attention to the role of political leaders in the "meta-governance" of public affairs in an example of network governance in sustainability transitions. Consequently, this article proceeds with exploring the relationship between political leadership in a context of network governance concerned with sustainability transitions and the democratic performance thereof. First, the dilemma underlying democratic legitimacy in network governance is further examined. Second, political leadership in sustainability transitions is further operationalized and understood as political meta-governance. Third, these theoretical conceptions are applied on a case of a state-centered process of network governance in a sustainability transition context: the Dutch National Agreement on Climate ("Nationaal Klimaatakkoord").

\section{Governing Sustainability Transitions and the Issue of Democratic Legitimacy}

Whereas traditional top-down decision-making assumed a predictable and relatively stable environment for decision-making to take place, the development of interactive governance processes that can be found in sustainability transitions is highly uncertain, causing complex decision-making processes [6,31]. Therefore, severe attention has been paid to attempts to manage and steer these processes, and keep track of their performance [10,32].

With the particular aim of facilitating transitions towards sustainability, a wide variety of specific transition-related modes of governance emerged [5,7]. In governing sustainability transitions, different modes of governance are elaborated in order to bring these transitions about. Some call for deliberate meta-governance strategies $[33,34]$, others call for institutionalized, overarching governance 
frameworks $[1,35,36]$ and others herald transition management as key to bring sustainability transitions about $[4,7,23,37]$.

Although these scholars acknowledge that transitions cannot be "managed" in a traditional way, they can be influenced and possibly accelerated with the correct application of particular governance activities [37]. These concerns, among others, meta-governance and network governance, multi-level governance, the multi-phase concept, strategic niche management and transition management $[4,7]$. Despite this variety, many of these modes of governance show similarities. As Loorbach finds, common elements concern "actor-network interaction, different levels, different social domains with specific characteristics, plurality of actor perspectives, and new instruments, practices, and approaches that emerge within the field of steering and government" [5]. The variety of empirical and theoretical conceptions concerned with sustainability clearly illustrates the urgency to find modes of governance that effectively facilitate them.

Specific dilemmas and barriers underlying the governance of sustainability transitions have been extensively debated. As illustrated, a persistent dilemma that comes with the emergence of interactive network governance is that, due to their constellation of public, private, and societal actors that "co-govern", network governance is no longer primarily focused on political realms of public sector government. Indeed, this holds important implications for their public legitimacy and accountability $[13,21,27,38,39]$. As Jhagroe correctly observes, "clearly, a main challenge in the context of transition management, are inherent tensions underlying existing democratic institutions and procedures." [28]. In addition, Van Buuren and Loorbach [40] have indicated that transition arenas are often becoming disconnected from official (political) decision-making and may therefore be lacking democratic legitimacy.

With regard to his examination of socio-technical transitions in the energy system, Meadowcroft notes that transition management supporters are often criticized for "being overly optimistic about the possibilities of displacing the existing regime, and for neglecting the political and power dimensions of transitions" [29] He puts forward that, in order to maintain democratically legitimate, transition management practice may be expected to "throw questions back into the political arena", since it is concerned with political choices, making it "hard to see how these could be made by anyone except a political authority." [29]. Hence, existing governmental institutions based on political representation retain to play an important role in organizing and steering sustainability transitions. To further enhance our understanding of the democratic implications of emergent modes of governance in sustainability transitions, we henceforward regard transition management as a particular mode of network governance [17].

One of the lenses through which the interrelatedness of existing political reality and the logic underlying network governance and sustainability transitions can be further understood, is meta-governance. Our focus on democratic values further calls for a broader emphasis on political legitimization, which is where transition management falls short. Meta-governance, on the other hand, explicitly addresses democratic legitimacy in a governance network context. Hence, this article will precede with conceptualizing the issue of democratic legitimacy in network governance, and the potential reconciliation between existing political institutions and network logic in the form of meta-governance.

\subsection{Assessing Democratic Legitimacy in Network Governance}

As illustrated above it is, on the one hand, widely agreed that governance in sustainability transitions relies strongly on the involvement of stakeholders, partnerships and "joint" governance efforts, which can be regarded as modes of network governance $[9,41,42]$. We particularly witness the emergence of network governance in sustainability transitions, as these tend to show a strong actor-network evolution $[5,6,23,43]$. It is argued that effective and legitimized governance requires the negotiated interaction between state and non-state actors [29,32,34]. 
On the other hand it is questionable whether interactive modes of governance contribute to enhanced legitimacy of the way governance is enacted $[41,44,45]$. Whereas state capacity "hinges upon its democratic authority and legitimacy", lent by elected officials, the rise of network governance as such has been argued to lead to a "bypass of the nation state", and therefore, the marginalization of state authority [46]. As Papadopoulos observes, "this policy style tends to replace the influence of the 'demos' (exerted through the designation of elected representatives) with a combination of group representation and influence tied to sectoral or local expertise" [47]. The question whether network governance threads or complements existing institutionalized forms of democratic legitimacy and state authority, thus, sparked an extensive scholarly debate $[27,30]$. How the democratic legitimacy of governance networks can be assessed, thus, is an important normative and empirical question.

In their elaboration of different models of democratic legitimacy in governance networks, Klijn and Edelenbos [48], and later Klijn and Koppenjan [10] arrive at three main sources of legitimacy that are a returning feature in different models of democracy. First, the way accountability is organized is an important, if not the most important source for democratic legitimacy [10,25]. Accountability, here, refers to the formal accountability of identifiable officeholders and procedures to hold them accountable [49]. Second, voice is core to the democratic legitimacy of network governance processes. This refers to the possibilities of citizens and actors to actively participate in decision-making processes, and the procedure of decision-making itself. As Papadopoulos puts it, "considerations of transparency, equal access and such like are likely to prevail in the assessment of decisional procedures" [45]. Elements such as fairness and accessibility can thus be considered elements of voice $[10,45]$. Third, due deliberation strongly refers to the quality of the interactive governance process and the process through which information and arguments are exchanged [10,30,48].

Thus, sources of democratic legitimacy in interactive governance arrangements can be found threefold; in accountability, in voice and in due deliberation. Sørensen, in studying the institutionalization of interactive governance, arrives at similar core features, although formulated slightly different: democratic inclusion, democratic deliberation and democratic accountability [26].

\subsection{Assessing the Role of Political Leadership in Sustainability Transitions}

Sustainability transitions are of inherently political nature. According to Meadowcroft, "Precisely because politics plays a potentially powerful role (defining the landscape, propping up or destabilizing regimes, protecting or exposing niches), it requires explicit attention from those interested in understanding sustainability transitions" [50]. When one is to further examine the notion of political leadership, one quickly finds that political leadership is transforming thoroughly [38,51-53].

Indeed, there is a wide consensus that governmental steering through merely top-down decision-making or markets does not suffice when addressing sustainability transitions $[5,9,22,50,54]$. Network-based modes of governance rely on the involvement of public, private and societal actors, and accordingly change the role of political leadership $[9,11,30]$. Consequently, the traditional role of elected officials as "sovereign rulers", based on the primacy of politics, morphs into the role of a "meta-governor" that distantly influences complex arrays of interacting actors by applying particular strategies $[38,48,53]$. The emergence of network governance thus demands a fundamental reappraisal of what it means to be a political leader. However, bringing about lasting political role innovation is difficult. In empirical analysis, Edelenbos et al. examine the rural development of the "Broekpolder" in the Netherlands, and find that political role innovation, providing more space for self-organization to take place, may come about, but is difficult to maintain [51]. Koppenjan et al. find that politicians on local levels of government take on a meta-governor role, concerning the restructuring of agricultural sites in the Netherlands [52].

One of the theoretical lenses through which political leadership in a polity in which power and resources are widely dispersed can be understood, thus, is meta-governance. Meta-governance was originally defined as "the organization of the conditions for governance in its broadest sense" [20]. Conceptualizing meta-governance as a way through which existing political institutions are able to 
steer governance networks, it may be generally regarded as the "regulation of self-regulation" [44,55]. "Danish-school" governance scholars such as Eva Sørensen and Jacob Torfing further elaborated the concept as "a reflexive and responsive process through which a range of legitimate and resourceful actors aim to combine, facilitate, shape and direct particular forms of governance in accordance with specific rules, procedures and standards." [8,44].

They propose meta-governance as an instrument which "enables politicians and public managers to exercise state power in a decentered polity in which power is dispersed within complex networks bringing together public and private actors from different levels and policy areas." [44]. Emphasizing the importance of the legitimacy issue, Carey Doberstein, in his examination of meta-governance in Canada, regards meta-governance as a notion that "captures the relationship and tension between the willingness of the state to engage with civil society representatives $(\ldots)$ via purpose-focused governance networks, while maintaining some degree of control over their activity consistent with traditional notions of democratic accountability" [25]. As Christopoulos et al. conclude in their study on sustainable development (SD) in Croatia, Nepal and Mongolia, national governments are "keen to take up programs for SD" and meta-govern by developing rules for engagement, thereby fostering deliberation among affected stakeholders [56]. Daugbjerg and Fawcett underline these findings by showing the strong role of Danish government in meta-governing cases of organic farming, and in doing so strengthening its democratic performance [57].

Regardless of the subtle differences in theoretical conceptualizations of meta-governance, its manifestation in practice appears to be a topic of a wider consensus. According to Bell and Hindmoor, the core functions of meta-governance are aimed at steering, effectiveness, mobilizing resources and ensuring fair, democratic and legitimate functioning of the network [18,25]. Complementing this conceptualization, Sørensen and Torfing emphasize the importance of framing and storytelling by governmental actors; that is, influencing the discourse surrounding the network [38,44]. In elaborating different strategies that may be used in order to enact meta-governance, Sørensen and Torfing provide a fourfold categorization, and distinguish "hands-off" and "hands-on" meta-governance (see Table 1).

Table 1. Hands-off and hands-on meta-governance strategies as identified by Sørensen \& Torfing.

\begin{tabular}{ll}
\hline Distance to Interactive Governance Arrangement & Meta-Governance Strategy \\
\hline \multirow{2}{*}{ Distant influencing: Hands-off meta-governance } & $\begin{array}{l}\text { Network design: influencing through e.g., scope, } \\
\text { character, composition, procedures } \\
\text { Network framing: influencing through e.g., political } \\
\text { goals, legal basis, storylines }\end{array}$ \\
& $\begin{array}{l}\text { Network management: providing material and } \\
\text { immaterial inputs to empower actors, resolve conflict, } \\
\text { reduce tensions etc. }\end{array}$ \\
& $\begin{array}{l}\text { Network participation: influencing e.g., the policy } \\
\text { agenda, decision-making, negotiated outputs etc. }\end{array}$ \\
\hline
\end{tabular}

Network design, here, concerns attempts aimed at influencing the scope of the governance network, its composition in terms of participants, and the design of internal procedures and processes. Network framing concerns influencing the "political goals, fiscal conditions, legal basis and the discursive storyline" of the governance network. Both can be considered "hands-off" as they are deployed distanced from the governance network itself, and concern activities that surround the network rather than interfere in its operations $[38,44,58]$.

"Hands-on" strategies, on the other hand, show direct interference within the operations of the governance network. These strategies fall apart in two main categories: network management and network participation. The first concerns attempts to "manage" the development of the network, such as reducing tensions among its members, empowering particular actors and lowering transaction costs by providing certain inputs. Here, an overlap with the "Dutch school" of network management can be 
witnessed [10]. The latter, network participation, concerns the meta-governor becoming one among many network participants, while retaining a "reflexive gaze" in order to influence its operations [44].

Both hands-off and hands-on meta-governance strategies can be considered complementary, reinforcing one another when deployed deliberately [38,44]. However, Torfing et al. put forward that politicians in particular are "in a privileged position as democratically legitimate exercisers of hands-off meta-governance through a legal, political and financial framing of interactive governance processes." [53]. When it comes to exercising hands-on meta-governance, their position is less fortunate as, e.g., participation may harm their independent status [59]. Nonetheless, "how politicians can exercise meta-governance in a way that grants them both a certain level of involvement in and a fair amount of independence from interactive governance arenas" remains a key question with regard to the role of political leaders in processes of network governance [59].

The elaborated strategies are argued to contribute to both effectiveness and democratic legitimacy of governance networks [44]. Network effectiveness may be enhanced by, inter alia, determining deadlines, fostering goal alignment, providing resources to lower transaction costs and developing trust [44]. Network democracy may be enhanced by, inter alia, assuring a broad inclusion of affected stakeholders through network design, setting a political, financial or discursive framework through network framing, assuring transparency through network management and enhancing a broad policy agenda by network participation $[25,44]$. Figure 1 indicates several ways through which meta-governance strategies may enhance both effectiveness and democracy of network governance processes [44].

\begin{tabular}{|c|c|c|}
\hline & Effectivity & Democracy \\
\hline \multirow[t]{3}{*}{ Network design } & $\begin{array}{l}\text { Keep a strict focus on objectives } \\
\text { and innovative capacities when } \\
\text { composing the network }\end{array}$ & $\begin{array}{l}\text { Ensure publicity about the } \\
\text { formation of the network and } \\
\text { the policy outputs it produces }\end{array}$ \\
\hline & $\begin{array}{l}\text { Define or negotiate clear } \\
\text { deadlines for different forms of } \\
\text { policy output from the network }\end{array}$ & $\begin{array}{l}\text { Ensure a broad inclusion of } \\
\text { relevant and affected actors } \\
\text { (avoid external exclusion) }\end{array}$ \\
\hline & $\begin{array}{l}\text { Terminate superfluous and } \\
\text { unsuccessful networks }\end{array}$ & $\begin{array}{l}\text { Create or support alternative } \\
\text { and competing networks }\end{array}$ \\
\hline \multirow[t]{3}{*}{ Network framing } & $\begin{array}{l}\text { Ensure coordination and } \\
\text { goal alignment through political } \\
\text { framing and storytelling }\end{array}$ & $\begin{array}{l}\text { Communicate the political, fiscal, } \\
\text { legal and discursive framework } \\
\text { conditions to the network }\end{array}$ \\
\hline & $\begin{array}{l}\text { Create strong interdependencies } \\
\text { among the network actors in order } \\
\text { to stimulate resource exchange }\end{array}$ & $\begin{array}{l}\text { Monitor the performance of } \\
\text { the network in relation to } \\
\text { the framework conditions }\end{array}$ \\
\hline & $\begin{array}{l}\text { Share effectiveness gains arising } \\
\text { from network governance with } \\
\text { the network and network actors }\end{array}$ & $\begin{array}{l}\text { Decide whether non-compliance } \\
\text { should lead to sanctions or } \\
\text { adjustments to the framework }\end{array}$ \\
\hline \multirow[t]{3}{*}{ Network management } & $\begin{array}{l}\text { Provide adequate resources that } \\
\text { lower the transaction costs and } \\
\text { empower the network actors }\end{array}$ & $\begin{array}{l}\text { Empower the weak and marginal- } \\
\text { ized network actors in order to pro- } \\
\text { mote equality within the network }\end{array}$ \\
\hline & $\begin{array}{l}\text { Reduce destructive tensions through } \\
\text { agenda control, arbitration, joint } \\
\text { fact-finding and cross-frame learning }\end{array}$ & $\begin{array}{l}\text { Ensure transparency through } \\
\text { the circulation of relevant } \\
\text { information }\end{array}$ \\
\hline & $\begin{array}{l}\text { Signal that a flexible adjustment of } \\
\text { ends and means is acceptable in } \\
\text { order to encourage innovation }\end{array}$ & $\begin{array}{l}\text { Probe whether the private stake- } \\
\text { holders enjoy the support of } \\
\text { their respective constituencies }\end{array}$ \\
\hline \multirow[t]{3}{*}{ Network participation } & $\begin{array}{l}\text { Facilitate sustained cooperation } \\
\text { by producing quick victories and } \\
\text { creating joint ownership of them }\end{array}$ & $\begin{array}{l}\text { Maintain a broad policy agenda } \\
\text { supported by a vaguely defined } \\
\text { story-line (avoid internal exclusion) }\end{array}$ \\
\hline & $\begin{array}{l}\text { Show trust in order to gain } \\
\text { and build trust }\end{array}$ & $\begin{array}{l}\text { Insist on an open and responsive } \\
\text { deliberation of alternative options }\end{array}$ \\
\hline & $\begin{array}{l}\text { Institutionalize processes } \\
\text { that work well and learn } \\
\text { from those that do not }\end{array}$ & $\begin{array}{l}\text { Ensure that the network evaluates } \\
\text { its own performance in relation to } \\
\text { common democratic standards }\end{array}$ \\
\hline
\end{tabular}

Figure 1. Meta-governance and effective and democratic network governance. Derived from Sørensen and Torfing 2009, p. 248 [44]).

\section{Research Methodology}

After having examined the relevant literature in the field of democratic legitimacy in governance networks in the context of sustainability transitions, we proceed with explaining our research approach. For this study, a qualitative research design was chosen: the case study approach. First, in collecting a rich variety of data, one of the strengths of a case study approach roots in its ability to include several sources of information on the specific case. These may involve observations, interviews, and policy documents. Second, case studies examine the object of study in its natural context rather than an artificial setting provided by e.g., experiments and survey research. Third, case studies have the 
ability to identify detailed social processes and causal mechanisms that underlie them. The case study approach offers the possibility to investigate in-depth relations between a variety of variables $[60,61]$.

Considering that this study particularly aims at getting a deep and rich understanding of meta-governance and its influence on democratic legitimacy, the case study provides a well-suited approach.

In doing so, we use the case of the Dutch National Agreement on Climate ("Nationaal Klimaatakkoord"). This agreement is expected to work towards measures embodying the national-level contribution of the Netherlands to the global objectives with regard to the reduction of greenhouse gas emissions (GHG) as formulated in the Paris agreement on climate, signed in 2015. The Dutch national government, however, decided to leave the exact formulation of measures up to affected stakeholders, rather than implementing measures top down, thereby choosing to use a network governance approach. These stakeholders constitute a governance network of private, societal, and public organizations. The Dutch government formulated the fixed ambition of a GHG reduction of $49 \%$ by 2030 . The involved actors are expected to further negotiate the particular measures that should mount up to this ambition. Considering the rich history of depoliticizing persistent societal issues in the Netherlands, captured in the notion of the "Poldermodel", this does not come as a surprise. The Poldermodel approach assumes negotiation between mutually dependent actors to foster societal support for measures to be implemented, as a broad representation of societal groups is included in the process of decision-making.

In terms of structure, the governance network process consists of five "sub-tables", composed content-wise, that are to arrive at measures mounting up to ex ante formulated objectives. These tables and their respective objectives in terms of megatons $\mathrm{CO}_{2}$ reduction are:

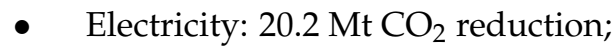

- Mobility: $7.3 \mathrm{Mt} \mathrm{CO}_{2}$ reduction;

- Industry: $14.3 \mathrm{MtCO}_{2}$ reduction;

- Agriculture and land use: $3.5 \mathrm{Mt} \mathrm{CO}_{2}$ reduction;

- Built environment: $3.4 \mathrm{Mt} \mathrm{CO}_{2}$ reduction.

The composition of the five sub-tables in terms of stakeholders is based on three criteria, that are to be met in order to be invited. Actors are invited when:

- They are able to contribute concretely to the transition within their sector;

- They bring in knowledge;

- They are able to make agreements based on a mandate.

Despite these criteria, the actors involved in the actual negotiations represent public, private, and societal groups on different levels. Examples of involved actors are NGOs such as Greenpeace, civil organizations such as the Association for Electric Drivers, companies such as Shell, Philips, and TataSteel, branched organizations such as LTO ('Land- en Tuinbouworganisatie', representing the agricultural sector) and the association of municipalities in the Netherlands (the "Vereniging Nederlandse Gemeenten"). The negotiations at those tables are led by an independent chair and are administratively facilitated by civil servants from the Ministry of Economic Affairs and Climate and other related ministries. The overall and politically accountable authority is the minister of Economic Affairs and Climate. The formal position of the minister, representing the executive power, also provides the formal linkage between the two demarcated arenas: the political arena of the Dutch parliament, and the governance arena in which the negotiating actors operate. Although opinions conflict upon whether this governance approach is favorable in the context of national climate policy, The Agreement on Climate thus is an important factor in the transition towards a more sustainable society in the Netherlands. 


\subsection{Research Strategy}

The data for this study is acquired in various ways. Source triangulation is used twofold. On the one hand, parliamentary documents, which are publicly accessible documents, are used to provide insights in the actual behavior of political meta-governors. This content analysis will proceed as follows:

- Parliamentary resolutions (In Dutch: "Moties"): Political meta-governors that are representative within a democratic system have the ability to govern through, among others, budgeting and regulations. These consist of proposals, captured in parliamentary resolutions, which are voted for in parliament. Therefore, our first source consists of all parliamentary resolutions including the terms "Klimaatakkoord" and "Klimaat-en Energieakkoord". Here, a selection is made of those concerning the actual "Klimaatakkoord" in the Netherlands, not to confuse with the global Paris agreement (in Dutch also referred to as "Klimaatakkoord"). Since meta-governance concerns attempts, resolutions that got rejected by voting are also taken into account.

- Parliamentary questions (In Dutch: "Kamervragen"): An important instrument of political meta-governors to control the executive power consists of asking parliamentary questions. Hence, these questions provide a crucial overview of what information is asked for by political meta-governors, and since these documents are made public, also what is desirable to be made transparent. In terms of democratic legitimacy, and in particular monitoring national-level climate governance, these questions thus incorporate highly relevant information. To capture all questions concerning the National Agreement on Climate ("Nationaal Klimaatakkoord"), the selection is based upon the same terms as mentioned above.

All documents mentioned above will be examined by using the online archive of the Dutch house of representatives, the "Tweede Kamer". This can be found at www.tweedekamer.nl. The formal starting point of the interactive governance process has been 23rd of February 2018. Since attempts to provide a framework in advance may be at stake, all documents from the start of the parliamentary year after the January 1st, 2018 until the execution of this study throughout June 2018, are taken into account.

To provide in-depth insights in the information found in both resolutions and questions, an additional source of this research will consist of interview subjects. Triangulation in terms of interview subjects is applied as well. We used two analytical categories of interview subjects. These are political actors and negotiating actors. This distinction is based on the respective governance arenas in which the actors are active. Political actors operate in the institutionalized, political realm of government, the Dutch house of representatives. Negotiating actors, on the other hand, operate in the governance network arena concerned with the National Agreement on Climate. We set out to examine the influence of meta-governance strategies deployed in the political arena, and how these influence the governance network arena.

Political actors, here, represent elected officials in the Dutch parliament ("Tweede Kamer") or their direct policy advisors in the domain of sustainability and/or renewable energy, and therefore affected by the National Agreement on Climate ("Nationaal Klimaatakkoord"). As this research concerns politics, the division between right-wing and left-wing politicians may determine the politicians' stance towards the agreement, as it concerns a political topic. Nevertheless, the focus on the process of governing rather than the content of the agreement is argued to cut across this traditional divide. Particularly note that political actors are relevant when it comes to the actual application of meta-governance strategies, and identification with the role of meta-governor.

Negotiating actors, on the other hand, are actors representing an organization in the actual negotiations on the National Agreement on Energy and Climate and thus members of one of the "sub-tables" as identified above. 


\subsection{Operationalization}

To examine political meta-governance strategies as well as the values of democratic legitimacy as elaborated above in an appropriate manner, the operationalization of these variables is presented in Figures 2 and 3. In literature on meta-governance, (political) meta-governance often inherently includes democratic legitimacy [38]. However, in additional literature meta-governance is also connected to the efficiency and effectiveness of governance networks [38]. Regarding the operationalization of both concepts, we therefore make a clear distinction between meta-governance on the one hand and democratic legitimacy on the other hand. This allows us to explicitly investigate the relationship between the types of political meta-governance and forms/aspects of democratic legitimacy.

\begin{tabular}{|c|c|c|}
\hline Meta-governance strategy & Operationalized & $\begin{array}{l}\text { Indicator(s) for meta- } \\
\text { governance strategies }\end{array}$ \\
\hline $\begin{array}{l}\text { Network design and } \\
\text { composition (hands-off) }\end{array}$ & $\begin{array}{l}\text { The meta-governor tries to } \\
\text { influence rules and followed } \\
\text { procedures } \\
\text { The meta-governor tries to } \\
\text { influence the composition of } \\
\text { the network }\end{array}$ & $\begin{array}{l}\text { Proposals regarding the } \\
\text { accountability of actors } \\
\text { Proposals regarding the } \\
\text { inclusiveness of the } \\
\text { network } \\
\text { Proposals regarding } \\
\text { internal procedures and } \\
\text { public transparency }\end{array}$ \\
\hline $\begin{array}{l}\text { Network framing (hands- } \\
\text { off) }\end{array}$ & $\begin{array}{l}\text { The meta-governor sets a } \\
\text { legal, financial and/or } \\
\text { discursive framework for the } \\
\text { governance network } \\
\text { The meta-governor monitors } \\
\text { the performance of the } \\
\text { network in terms of the } \\
\text { surrounding framework }\end{array}$ & $\begin{array}{l}\text { Proposals regarding } \\
\text { legislation/regulations } \\
\text { Proposals regarding } \\
\text { financial means/budget } \\
\text { Proposals to determine } \\
\text { what topics are on the } \\
\text { agenda } \\
\text { Asking for information on } \\
\text { the governance network }\end{array}$ \\
\hline $\begin{array}{l}\text { Managing the network } \\
\text { (hands-on) }\end{array}$ & $\begin{array}{l}\text { The meta-governor directly } \\
\text { interferes by providing } \\
\text { resources and empowering } \\
\text { actors } \\
\text { The meta-governor } \\
\text { deliberately distributes } \\
\text { resources and knowledge and } \\
\text { assures fair circulation }\end{array}$ & $\begin{array}{l}\text { Proposals regarding what } \\
\text { information is to be used } \\
\text { by whom } \\
\text { Proposals regarding the } \\
\text { position of particular } \\
\text { actors within the network }\end{array}$ \\
\hline $\begin{array}{l}\text { Participating in the } \\
\text { network (hands-on) }\end{array}$ & $\begin{array}{l}\text { The meta-governor actively } \\
\text { engages in interaction among } \\
\text { actors within the governance } \\
\text { network }\end{array}$ & $\begin{array}{l}\text { Formal and informal } \\
\text { meetings with negotiating } \\
\text { actors } \\
\text { Participation in meetings } \\
\text { Participation in organized } \\
\text { events }\end{array}$ \\
\hline
\end{tabular}

Figure 2. Operationalization of meta-governance strategies.

\begin{tabular}{|l|l|l|}
\hline $\begin{array}{l}\text { Value of democratic } \\
\text { legitimacy }\end{array}$ & Operationalized & $\begin{array}{l}\text { Indicator(s) for } \\
\text { democratic legitimacy }\end{array}$ \\
\hline Accountability & $\begin{array}{l}\text { Allocated accountability } \\
\text { throughout all stages of } \\
\text { the process }\end{array}$ & $\begin{array}{l}\text { Involved actors feel } \\
\text { accountable towards } \\
\text { existing } \\
\text { representational } \\
\text { institutions }\end{array}$ \\
\hline Voice & $\begin{array}{l}\text { Involvement of actors in } \\
\text { all stages of the } \\
\text { governance process }\end{array}$ & $\begin{array}{l}\text { Involved actors } \\
\text { perceive the } \\
\text { governance network } \\
\text { as inclusive rather } \\
\text { than exclusive }\end{array}$ \\
\hline Due deliberation & $\begin{array}{l}\text { The quality of the } \\
\text { deliberation at all stages } \\
\text { of the governance process } \\
\text { The transparency } \\
\text { throughout all stages of } \\
\text { the governance process }\end{array}$ & $\begin{array}{l}\text { Actors' satisfaction } \\
\text { with the quality of } \\
\text { deliberation (exchange } \\
\text { of arguments) }\end{array}$ \\
$\begin{array}{l}\text { Actors' satisfaction } \\
\text { with the degree of } \\
\text { transparency }\end{array}$ \\
\hline
\end{tabular}

Figure 3. Operationalization of democratic legitimacy. 


\section{Results}

We set out to measure the democratic legitimacy of the governance network concerned with the Agreement on Climate. In doing so, the following elements of democratic legitimacy were examined:

- Accountability;

- Voice;

- Due deliberation.

This section will proceed with some general observations based on the examined data and the interviews that followed, and thereafter explicitly address the three indicators mentioned above. To study the democratic legitimacy, particularly, the interviews with political and negotiating actors were important.

\subsection{The Democratic Legitimacy of Interactive Climate Governance in the Netherlands}

Overall, the gathered data suggest a relative strong anchorage of the interactive governance process regarding existing representative institutions. The controlling and framing powers of the Dutch Parliament are safeguarded both in terms of input (explicitly discussing the framework for the governance network with parliament in advance), throughput (organized interfaces throughout the governance process) and output (the final balancing of the produced agreement and decision-making by parliament).

Furthermore, the minister of Economic Affairs and Climate, representing the executive branch of government, is perceived as the "accountee" on which account is to be rendered. This indeed is in accordance with the formal division of powers, as the parliament represents the controlling and framing power, and the minister represents the executive power. In a sense, the primacy of politics, thus, it not explicitly challenged.

Nonetheless, the interactive approach concerning the Agreement on Climate holds implications for the role of existing political institutions. Political actors express to feel a "threshold" to exercise their formal power, as the governance process is expected to result in a "carefully constructed, well balanced" agreement based on a balance between "sweet and sour" regarding the interests of all actors. Changing things that are politically unfeasible and/or undesirable will "make this construction collapse" and may eventually cause actors to leave the network. Political actors, hence, express their anxiety to act like a "bull in a china shop" when they actively interfere with the carefully constructed agreements that are presented to them.

Negotiating actors, on the other hand, do feel accountable to "come up with an agreement that is politically feasible", as they take into account the strong position of the parliament.

Although a certain degree of accountability towards existing political institutions is felt, the particular concern of negotiating actors are their own constituencies.

Some of the negotiating actors explicitly address the felt "shadow or hierarchy" casted by the clear presence of the minister of Economic Affairs and Climate. Indeed, the explicit role and "representation of government" in the interactive governance process by civil servants cast a shadow of hierarchy, as actors are well aware of the ability of the minister to use "law and regulations we have less influence over" if negotiating actors "won't arrive at the $49 \%$ goal". This formal power of the minister is referred to as a "stick behind the door" which actors are constantly aware of.

The transparency of the process is valued very low to zero. As an MP expresses, he "knows as much as presented in the media", and therefore has no more information than any other citizen. Although some political actors perceive this as negative, there is understanding as well-an MP argues that "we should not disturb the chicken while she's breeding". The final judgement which is allocated in parliament encourages political actors to "patiently await" the result, because they know "there will be extensive political debate" on the delivered outputs in later stages of the process.

The democratic legitimacy of interactive climate governance in the Netherlands in terms of accountability can be valued high. This study reported high levels of accountability on the 
side of political representative institutions. Indeed, the anchorage of interactive governance in a democratically legitimized governmental policy was shown to strengthen the role of existing representative institutions.

Furthermore, existing structures regarding the division of accountability are not challenged, as executive powers, in the studied case represented by the minister of Economic Affairs and Climate, are formally accountable for the governance process. The decision of the minister to use interactive governance as an instrument to enhance societal commitment and support, and use expertise of private, public, and societal actors have been reported as arguments that are recognized and supported by the Dutch Parliament. Negotiating actors do feel accountable towards public authorities, particularly to arrive at politically feasible solutions. Accordingly, political accountability is anchored relatively strong. Due to ex ante framework setting by means of the Coalition Agreement, making steering beforehand and monitoring afterwards possible, a vertical accountability relationship between representative institutions and the governance network is established.

Despite specific attempts to "strengthen the relationship between governance network and citizens" the democratic legitimacy of interactive climate governance in the Netherlands in terms of voice can be valued medium. Although, indeed, the reported findings suggest an interactive governance arena in which a wide variety of substantive interests and arguments have been involved, actors needed to adhere to formulated access criteria and proactively impose their involvement in the governance network. This demands thought-through organization, and indeed excludes societal groups with fewer capacity to do so. Accordingly, the direct involvement of citizens has been clearly limited. Generally, MP's aim at safeguarding an overall general balance between "progressive and conservative powers" in the network rather than being concerned with the involvement of specific actors.

The democratic legitimacy of interactive climate governance in the Netherlands in terms of $d u e$ deliberation can be valued as medium. Although the public transparency of the deliberation within the network is valued as "low to zero", this is not perceived problematic. It is argued that, although the transparency of the governance arena is low, it is also "as high as possible". Both political and negotiating actors acknowledge that a certain degree of secrecy is needed in order to negotiate properly.

The degree to which transparency was organized particularly underlines the "state-centered" character of governance in this case, as "the degree of transparency of state-centered governance is very much controlled by the government itself" [62]. Among others, this is shown by in-between briefings organized by government and an in-between press release, planned in advance. These underline the governmental influence over the degree of transparency.

\subsection{The Application of Political Meta-Governance}

We operationalized political leadership as political meta-governance. To identify the actual application of political meta-governance strategies, results from both parliamentary data and interviews with potential meta-governors are used. To recall, the meta-governance strategies that might be exercised were identified as [45]:

- Network framing (hands-off);

- Network design (hands-off);

- Network management (hands-on);

- Network participation (hands-on).

Reflecting on political meta-governance, first and foremost, it is relevant to demarcate the executive branch of government from the controlling branch of government, which holds executive government to account [63]. Indeed, the Dutch Parliament concerns the controlling branch of government, and as such, exercises democratic control. A returning feature in the research findings reported above, is that MP's that constitute this controlling branch perceive many of the identified meta-governance strategies as particular roles for the executive branch of government. Accordingly, the minister of Economic Affairs and Climate performs a considerable job as meta-governor. Since 
political meta-governance as defined in this study explicitly addresses the role of Members of Parliament, however, we will now turn towards the role of MP's meta-governing the interactive climate-governance process concerning the Dutch Agreement on Climate.

There is wide consensus concerning the necessity for network governance with regard to climate policy in the Netherlands. Both political actors and negotiating actors agree that this interactive governance approach has significant advantages in comparison to top-down governmental policies. Among others, these concern societal expertise ("know-how"), commitment, the organization of societal support and, generally, smooth policy implementation in later phases. Hence, this particularly concerns the "governability" and "instrumental" argument of interactive governance, an attempt to "strengthen policy capacity" [18].

Indeed, the application of meta-governance strategies was shown to have come about in the case of the Dutch Agreement on Climate. The occurrence of network framing and network participation is considerably more often than are network design and network management. Network framing particularly concerned discursive framing, which some political actors directly relate to their agenda-setting role. Examples are resolutions aimed at broadening the scope of the "sub-tables", for instance by including emissions due to aviation and shipping (which were formerly excluded) and the labor-related impact of the energy transition. Indeed, this has to do with the soft application of Authority by political actors [36]. Aims to influence the "overall objective" and "joint mission" of the governance network were explicitly reported [44]. Topics that were to be addressed concern, among others, the size of livestock in the Netherlands, the division of societal costs brought forward by the energy transition and reluctant, obstructing regulations that hinders companies to enhance their sustainability performance. The setting of a framework within which actors operate can be considered a traditional task of Dutch representative bodies, building on vertical hierarchy rather than horizontal steering, and is accordingly referred to as "government of governance" [52]. Negotiating actors report to be aware of this framework, and indeed have obtained a "clear idea of what the political system conceives as politically feasible and appropriate" [44].

Network participation particularly concerned informal contacts with representatives of actors that were involved in the network, which should not be seen separately from already established relationships that concern lobbying in a more traditional sense. Hence, these relationships were not specifically established to discuss and steer the particular interactive governance arena. Rather, already established relationships were used to, next to "regular" fine-tuning and lobbying, address the Agreement on Climate as well.

From the side of political actors, this application of network participation was particularly aimed at "keeping up to date" of developments within the network, whereas negotiating actors used their contacts to "explore what topics were politically feasible", due to their awareness of the strong position of the Dutch Parliament in the final decision-making.

Both network design and network management occurred scarcely concerning the interactive governance process. Political actors particularly regard both strategies as part of the role performed by the minister of Economic Affairs and Climate, representing the executive branch of government.

Nonetheless, this study reports sporadic attempts to influence the composition of the network or the rules of the game. These concerned attempts to safeguard the particular position of certain actors, to enhance the transparency of the governance process as such or to add actors to the governance process. Some elected officials acknowledged that limited organizational capacity and other political priorities played a role in their limited application of meta-governance strategies.

An overview of the applied meta-governance strategies through submitting resolutions and asking parliamentary questions is provided in the Figures 4-7 below. 


\begin{tabular}{|c|c|c|c|c|c|c|}
\hline $\begin{array}{l}\text { Document- } \\
\text { code }\end{array}$ & Petitioner & Sub-petitioners & Content of request (dictate) & Indicator & Operationalized & $\begin{array}{l}\text { Meta-governance } \\
\text { strategy }\end{array}$ \\
\hline $\begin{array}{l}34627 \\
\text { Nr. } 35\end{array}$ & $\begin{array}{l}\text { Kops (Party } \\
\text { For (1) } \\
\text { Freedom) }\end{array}$ & & $\begin{array}{l}\text { Requests the Cabinet to proceed the conversations with } \\
\text { third parties (e.g. NGO's, net-managers and companies) } \\
\text { regarding the National Agreement on Climate in publicity }\end{array}$ & $\begin{array}{l}\text { Proposals regarding } \\
\text { internal procedures } \\
\text { and public } \\
\text { transparency }\end{array}$ & $\begin{array}{l}\text { The meta-governor tries to } \\
\text { influence the internal rules and } \\
\text { followed procedures }\end{array}$ & $\begin{array}{l}\text { Network design (hands- } \\
\text { off) }\end{array}$ \\
\hline $\begin{array}{l}30196 \\
\text { Nr. } 575\end{array}$ & $\begin{array}{l}\text { Van der Lee } \\
\text { (Greens) }\end{array}$ & $\begin{array}{l}\text { Yesilgozz-Zegerius } \\
\text { (Ulberals) } \\
\text { Jetten (Democrats) } \\
\text { Wassenberg (Party for the } \\
\text { Animals) } \\
\text { Dik-Faber (Christian } \\
\text { Union) } \\
\text { Moorlag (Labour) } \\
\text { Sazzias (50Plus) } \\
\text { Beckerman (Socialist } \\
\text { Party) }\end{array}$ & $\begin{array}{l}\text { Requests the Cabinet to inform the Parliament halfway } \\
\text { June regarding the constitution of the 'Climate-tables', } \\
\text { working groups and the general progress regarding the } \\
\text { National Agreement on limate }\end{array}$ & $\begin{array}{l}\text { Asking for } \\
\text { information on the } \\
\text { governance } \\
\text { network }\end{array}$ & $\begin{array}{l}\text { The meta-governor monitors } \\
\text { the performance of the } \\
\text { network in terms of the } \\
\text { surrounding framework }\end{array}$ & $\begin{array}{l}\text { Network framing (hands- } \\
\text { off) }\end{array}$ \\
\hline $\begin{array}{l}32813 \\
\text { Nr. } 176\end{array}$ & $\begin{array}{l}\text { Van Raan } \\
\text { (Party for } \\
\text { the Animals }\end{array}$ & & $\begin{array}{l}\text { Requests the Cabinet to safeguard a certain degree of } \\
\text { felexilitity within the Argeement on Climate, in the case } \\
\text { adjustments may be necessary to achieve the set climate } \\
\text { goals }\end{array}$ & $\begin{array}{l}\text { Proposalis regarding } \\
\text { internal procedures } \\
\text { and public } \\
\text { transparency }\end{array}$ & $\begin{array}{l}\text { The meta-governor tries to } \\
\text { influence the internal rules and } \\
\text { followed procedures }\end{array}$ & $\begin{array}{l}\text { Network design (hands- } \\
\text { off) }\end{array}$ \\
\hline $\begin{array}{l}30196 \\
\text { Nr. } 582\end{array}$ & $\begin{array}{l}\text { Wassenberg } \\
\text { (Party for } \\
\text { the Animals }\end{array}$ & $\begin{array}{l}\text { Moorlag (Labour) } \\
\text { Van der Lee (Greens) } \\
\text { Beckerman (Socialist } \\
\text { Party) }\end{array}$ & $\begin{array}{l}\text { Requests the Cabinet to explicitly address the shrinkage of } \\
\text { the amount of cartle during the negotiations on the } \\
\text { Agreement on Climate }\end{array}$ & $\begin{array}{l}\text { Proposals to } \\
\text { determine what } \\
\text { topics are on the } \\
\text { agenda }\end{array}$ & $\begin{array}{l}\text { The meta-governor sets a } \\
\text { financial, legal or discursive } \\
\text { framework for the governance } \\
\text { network }\end{array}$ & $\begin{array}{l}\text { Network framing (hands- } \\
\text { off) }\end{array}$ \\
\hline $\begin{array}{l}30196 \\
\text { Nr. } 581\end{array}$ & $\begin{array}{l}\text { Wassenberg } \\
\text { (Party for } \\
\text { the Animals) }\end{array}$ & $\begin{array}{l}\text { Beckerman (Socialist } \\
\text { Party) } \\
\text { Sazias (50Plus) }\end{array}$ & $\begin{array}{l}\text { Requests the Cabinet to adjust the goals as formulated in } \\
\text { the Agreement on Climate periodically if developments } \\
\text { enable this }\end{array}$ & $\begin{array}{l}\text { Proposals regarding } \\
\text { internal procedures } \\
\text { and public } \\
\text { transparency }\end{array}$ & $\begin{array}{l}\text { The meta-governor tries to } \\
\text { influence the internal rules and } \\
\text { followed procedures }\end{array}$ & $\begin{array}{l}\text { Network design (hands- } \\
\text { off) }\end{array}$ \\
\hline $\begin{array}{l}30196 \\
\text { Nr. } 594\end{array}$ & $\begin{array}{l}\text { Sazias } \\
\text { (50Plus) }\end{array}$ & $\begin{array}{l}\text { Van der Lee (Greens) } \\
\text { Moorlag (Labour) } \\
\text { Beckerman (Socialist } \\
\text { Party) }\end{array}$ & $\begin{array}{l}\text { Requests the Cabinet to, during the elaboration of the } \\
\text { Agreement on Climate, aim at a capacity-proportional } \\
\text { divide of costs in society where possible }\end{array}$ & $\begin{array}{l}\text { Proposals to } \\
\text { determine what } \\
\text { topics are on the } \\
\text { agenda }\end{array}$ & $\begin{array}{l}\text { The meta-governor sets a } \\
\text { financial, legal or discursive } \\
\text { framework for the governance } \\
\text { network }\end{array}$ & $\begin{array}{l}\text { Network framing (hands- } \\
\text { off) }\end{array}$ \\
\hline $\begin{array}{l}29023 \\
\text { Nr. } 234\end{array}$ & $\begin{array}{l}\text { Moorlag } \\
\text { (Labour) }\end{array}$ & $\begin{array}{l}\text { Van der Lee (Greens) } \\
\text { Beckerman (Socialist } \\
\text { Party) }\end{array}$ & $\begin{array}{l}\text { Requests the Cabinet to include agreements on } \\
\text { sustainabilitiv-criteris for production- and supply- } \\
\text { companies of energy when those are privatized by } \\
\text { shareholding governments }\end{array}$ & $\begin{array}{l}\text { Proposals to } \\
\text { determinine what } \\
\text { topics are on the } \\
\text { agenda }\end{array}$ & $\begin{array}{l}\text { The meta-governor sets a } \\
\text { financial, legal or discursive } \\
\text { framework for the governance } \\
\text { network }\end{array}$ & $\begin{array}{l}\text { Network framing (hands- } \\
\text { off) }\end{array}$ \\
\hline $\begin{array}{l}30196 \\
\text { Nr. } 596\end{array}$ & $\begin{array}{l}\text { Van der Lee } \\
\text { (Greens) }\end{array}$ & $\begin{array}{l}\text { Beckerman (Socialist } \\
\text { Party) } \\
\text { Moorlag (Labour) } \\
\text { Sazias (50Plus) }\end{array}$ & $\begin{array}{l}\text { Requests the Cabinet to stimulate that the transparency } \\
\text { of the used calculations for assessing the Agreement on } \\
\text { Climate, in particular by the Dutch Environmental } \\
\text { Assessment Agency (PBL), is as high as possible }\end{array}$ & $\begin{array}{l}\text { Proposals regarding } \\
\text { internal procedures } \\
\text { and public } \\
\text { transparency }\end{array}$ & $\begin{array}{l}\text { The meta-governor tries to } \\
\text { influence the internal rules and } \\
\text { followed procedures }\end{array}$ & $\begin{array}{l}\text { Network design (hands- } \\
\text { off) }\end{array}$ \\
\hline
\end{tabular}

Figure 4. The application of meta-governance strategies through submitted resolutions (1) 


\begin{tabular}{|c|c|c|c|c|c|c|}
\hline $\begin{array}{l}\text { Document- } \\
\text { code }\end{array}$ & $\begin{array}{l}\text { Petitioner } \\
\text { Pent }\end{array}$ & Question title & Content of coded questions & Indicator & Operationalized & $\begin{array}{l}\text { Meta-governance } \\
\text { strategy }\end{array}$ \\
\hline 2018205436 & $\begin{array}{l}\text { Van Raan } \\
\text { (Party for } \\
\text { the Animals) }\end{array}$ & $\begin{array}{l}\text {...about the scientific } \\
\text { anchorage of the } \\
\text { Agreement on Climate }\end{array}$ & 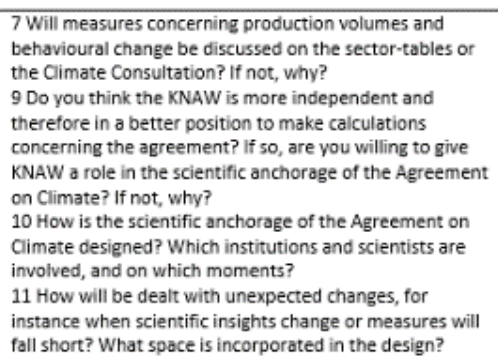 & $\begin{array}{l}\text { Asking for } \\
\text { information on the } \\
\text { governance } \\
\text { network } \\
\text { Proposals regarding } \\
\text { the position of } \\
\text { particular actors } \\
\text { within the network }\end{array}$ & $\begin{array}{l}\text { The meta-governor monitors } \\
\text { the performance of the } \\
\text { network in terms of the } \\
\text { surrounding framework } \\
\text { The meta-governotries to } \\
\text { influence the composition of } \\
\text { the network }\end{array}$ & $\begin{array}{l}\text { Network framing (hands- } \\
\text { off) } \\
\text { Network management } \\
\text { (hands-on) }\end{array}$ \\
\hline 2018204049 & $\begin{array}{l}\text { Wassenberg } \\
\text { (Party for } \\
\text { the Animals }\end{array}$ & $\begin{array}{l}\text {..about the message } \\
\text { Wood-burning in } \\
\text { neighbourhoods should } \\
\text { be stopped'. }\end{array}$ & 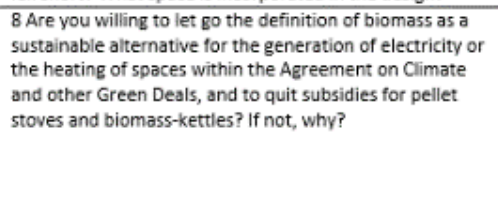 & $\begin{array}{l}\text { Proposals to } \\
\text { determine what } \\
\text { topiss are on the } \\
\text { agenda } \\
\text { Proposals regarding } \\
\text { internal procedures } \\
\text { and public } \\
\text { transparency }\end{array}$ & $\begin{array}{l}\text { The meta-governor sets a } \\
\text { financial, legal or discursive } \\
\text { framework for the governance } \\
\text { network } \\
\text { The meta-governor tries to } \\
\text { influence the internal rules and } \\
\text { followed procedures }\end{array}$ & $\begin{array}{l}\text { Network design (hands- } \\
\text { off) } \\
\text { Network framing (hands- } \\
\text { off) }\end{array}$ \\
\hline 2018208677 & $\begin{array}{l}\text { Wassenberg } \\
\text { (Party for } \\
\text { the Animals) }\end{array}$ & $\begin{array}{l}\text {..about the message that } \\
\text { the co-firing of biomass } \\
\text { causes a significant } \\
\text { increase of particulate } \\
\text { matter }\end{array}$ & $\begin{array}{l}8 \text { Are vou willing to let go the definition of biomass as a } \\
\text { sustainabie alternative for the generation of electricity or } \\
\text { the heating of spaces within the Agreement on Climate } \\
\text { and other Green Deals, and to quit subsidies for pellet } \\
\text { stoves and biomass-ketrles? If not, why? }\end{array}$ & $\begin{array}{l}\text { Proposals to } \\
\text { determine what } \\
\text { topies are on the } \\
\text { agenda } \\
\text { Proposals regarding } \\
\text { internal procedures } \\
\text { and public } \\
\text { transparency }\end{array}$ & $\begin{array}{l}\text { The meta-governor sets a } \\
\text { financial, legal or discursive } \\
\text { framework for the governance } \\
\text { network } \\
\text { The meta-governor tries to } \\
\text { influence the internal rules and } \\
\text { followed procedures }\end{array}$ & $\begin{array}{l}\text { Network design (hands- } \\
\text { off) } \\
\text { Network framing (hands- } \\
\text { off) }\end{array}$ \\
\hline 2018203953 & $\begin{array}{l}\text { Kröger } \\
\text { (Greens) }\end{array}$ & $\begin{array}{l}\text { about wind turbines and } \\
\text { Lelystad Airport }\end{array}$ & $\begin{array}{l}3 \text { How are you going to prevent that the expansion of } \\
\text { Lelystad Airport vill interfere with the governmental } \\
\text { ambitions to realize wind turbines in the region of } \\
\text { Flevoland, and therefore hinders the already concluded } \\
\text { Energy-agreement, and the yet-to-conclude Agreement } \\
\text { on Climate? }\end{array}$ & & & \\
\hline
\end{tabular}

Figure 5. The application of meta-governance strategies through submitted resolutions (2). 


\begin{tabular}{|c|c|c|c|c|c|c|}
\hline $\begin{array}{l}\text { Document- } \\
\text { code }\end{array}$ & Petitioner & Sub-petitioners & Content of request (dictate) & Indicator & Operationalized & $\begin{array}{l}\text { Meta-governance } \\
\text { strategy }\end{array}$ \\
\hline $\begin{array}{l}30196 \\
\text { Nr. } 577\end{array}$ & $\begin{array}{l}\text { Van der Lee } \\
\text { (Greens) }\end{array}$ & $\begin{array}{l}\text { Moorlag (Labour) } \\
\text { Sazias (50Plus) } \\
\text { Wassenberg (Party for the } \\
\text { Animals) }\end{array}$ & $\begin{array}{l}\text { Requests the Cabinet to involve the } \\
\text { financial sector in the Agreement on } \\
\text { Climate and look for possibilities to } \\
\text { enhance sustainable investment-portfolios }\end{array}$ & $\begin{array}{l}\text { Proposals regarding the } \\
\text { inclusiveness of the governance } \\
\text { network }\end{array}$ & $\begin{array}{l}\text { The meta-governor tries to } \\
\text { influence the composition } \\
\text { of the network }\end{array}$ & $\begin{array}{l}\begin{array}{l}\text { Network design and } \\
\text { composition (hands- } \\
\text { off) }\end{array} \\
\end{array}$ \\
\hline $\begin{array}{l}34723 \\
\text { Nr. } 20\end{array}$ & $\begin{array}{l}\text { Jetten } \\
\text { (Democrats) }\end{array}$ & Dik-Faber (Christian Union) & $\begin{array}{l}\text { Requests the Cabinet to inform citizens } \\
\text { about the sustainability of their heat- } \\
\text { source; } \\
\text { Requests the Cabinet to make agreements } \\
\text { with the sector to enhance the } \\
\text { sustainability of heat-supply } \\
\end{array}$ & $\begin{array}{l}\text { Proposals to determine what } \\
\text { topics are on the agenda }\end{array}$ & $\begin{array}{l}\text { The meta-governor sets a } \\
\text { financial, legal or discursive } \\
\text { framework for the } \\
\text { governance network }\end{array}$ & \begin{tabular}{|l}
$\begin{array}{l}\text { Network framing } \\
\text { (hands-off) }\end{array}$ \\
(hat)
\end{tabular} \\
\hline $\begin{array}{l}31936 \\
\mathrm{Nr} .450\end{array}$ & $\begin{array}{l}\text { Kröger } \\
\text { (Greens) }\end{array}$ & Van der Lee (Greens) & $\begin{array}{l}\text { Requests the Cabinet to stimulate that the } \\
\text { Mobility-table, in relation to the } \\
\text { Agreement on Climate, involves the Co2- } \\
\text { reduction of the aviation sector in their } \\
\text { negotiations }\end{array}$ & $\begin{array}{l}\text { Proposals to determine what } \\
\text { topics are on the agenda }\end{array}$ & $\begin{array}{l}\text { The meta-governor sets a } \\
\text { financial, legal or discursive } \\
\text { framework for the } \\
\text { governance network }\end{array}$ & $\begin{array}{l}\text { Network framing } \\
\text { (hands-off) }\end{array}$ \\
\hline $\begin{array}{l}30196 \\
\text { Nr. } 595\end{array}$ & $\begin{array}{l}\text { Yesilgöz- } \\
\text { Zegerius } \\
\text { (Liberals) }\end{array}$ & Jetten (Democrats) & $\begin{array}{l}\text { Requestst the Cabinet to add a crosss- } \\
\text { sectional theme to the elaboration of the } \\
\text { Agreement on Climate, 'obstructing } \\
\text { regulations' }\end{array}$ & $\begin{array}{l}\text { Proposals to determine what } \\
\text { topics are on the agenda }\end{array}$ & $\begin{array}{l}\text { The meta-governor sets a } \\
\text { financial, legal or discursive } \\
\text { framework for the } \\
\text { governance network }\end{array}$ & $\begin{array}{l}\text { Network framing } \\
\text { (hands-off) }\end{array}$ \\
\hline $\begin{array}{l}30196 \\
\text { Nr. } 585\end{array}$ & $\begin{array}{l}\text { Mulder } \\
\text { (Christian } \\
\text { Democrats) }\end{array}$ & $\begin{array}{l}\text { Yesilgöz-Zegerius (Liberals) } \\
\text { Jetten (Democrats) } \\
\text { Van der Lee (Greens) } \\
\text { Dik-Faber (Christian Union) } \\
\text { Moorlag (Labour) } \\
\text { Sazias (50Plus) } \\
\text { Beckerman (Socialist Party) }\end{array}$ & $\begin{array}{l}\text { Requests the Cabinet to, while elaborating } \\
\text { the Agreement on Climate, provide the } \\
\text { opportunity for citizens and small } \\
\text { businesses to deliver inputs, e.g. by } \\
\text { internet consultation }\end{array}$ & $\begin{array}{l}\text { Proposals regarding the } \\
\text { inclusiveness of the governance } \\
\text { network } \\
\text { Proposals regarding internal } \\
\text { procedures and public } \\
\text { transparency }\end{array}$ & $\begin{array}{l}\text { The meta-governor tries to } \\
\text { influence the composition } \\
\text { of the network } \\
\text { The meta-governor tries to } \\
\text { influence the internal rules } \\
\text { and followed procedures }\end{array}$ & $\begin{array}{l}\text { Network design and } \\
\text { composition } \\
\text { Network kraming } \\
\text { (hands-off) }\end{array}$ \\
\hline $\begin{array}{l}34672 \\
\text { Nr. } 34\end{array}$ & $\begin{array}{l}\text { Kops (Party For } \\
\text { Freedom) }\end{array}$ & & \begin{tabular}{|l|} 
Requests the Cabinet to stop all payments \\
regarding the energy transition and assure \\
the energy-bill for households will decrease
\end{tabular} & $\begin{array}{l}\text { Proposals regarding financial } \\
\text { means and budget }\end{array}$ & $\begin{array}{l}\text { The meta-governor sets a } \\
\text { financial, geval or discursive } \\
\text { framework for the } \\
\text { governance network }\end{array}$ & $\begin{array}{l}\text { Network framing } \\
\text { (hands-off) }\end{array}$ \\
\hline $\begin{array}{l}30196 \\
\mathrm{Nr} .580\end{array}$ & $\begin{array}{l}\text { Wassenberg } \\
\text { (Party for the } \\
\text { Animals) }\end{array}$ & $\begin{array}{l}\text { Van der Lee (Greens) } \\
\text { Moorlag (Labour) } \\
\text { Sazias (50Plus) } \\
\text { Beckerman (Socialist Party) }\end{array}$ & $\begin{array}{l}\text { Requests the Cabinet to invite a sufficient } \\
\text { amount of nature-and environmental } \\
\text { organizations (NGO's) to the sector-tables } \\
\text { in which the negotiations on the } \\
\text { Agreement on Climate will take place }\end{array}$ & $\begin{array}{l}\text { Proposals regarding the } \\
\text { inclusiveness of the governance } \\
\text { network } \\
\text { Proposals regarding the } \\
\text { position of particular actors } \\
\text { within the network }\end{array}$ & $\begin{array}{l}\text { The meta-governor tries to } \\
\text { influence the composition } \\
\text { of the network }\end{array}$ & $\begin{array}{l}\text { Network design and } \\
\text { composition (hands- } \\
\text { off) } \\
\text { Network } \\
\text { management (hands- } \\
\text { on) }\end{array}$ \\
\hline
\end{tabular}

Figure 6. The application of meta-governance strategies by submitted parliamentary questions (1). 


\begin{tabular}{|c|c|c|c|c|c|c|}
\hline $\begin{array}{l}\text { Document- } \\
\text { code }\end{array}$ & Petitioner & Question title & Content of coded questions & Indicator & Operationalized & $\begin{array}{l}\text { Meta-governance } \\
\text { strategy }\end{array}$ \\
\hline 2018208358 & $\begin{array}{l}\text { Van der Lee } \\
\text { (Greens) }\end{array}$ & $\begin{array}{l}\text {...bout the risks of } \\
\text { overload of the } \\
\text { electricity yupply for the } \\
\text { digital front-punners' } \\
\text { position of the } \\
\text { Netherlands }\end{array}$ & $\begin{array}{l}21 \text { s it true that there is a threatening shortage of } \\
\text { electricity-supply on favourable locations for data-centres, } \\
\text { e.g. Schiphol, Amsterdam Science Park and Amsterdam } \\
\text { South-East? } \\
10 \text { Are you, concluding, willing to promote the discussion } \\
\text { of these matters at the Electricity-table of the Agreement } \\
\text { on Climate? }\end{array}$ & $\begin{array}{l}\text { Proposals to } \\
\text { determine what } \\
\text { topics are on the } \\
\text { agenda }\end{array}$ & $\begin{array}{l}\text { The meta-governor sets a } \\
\text { financial, legal or discursive } \\
\text { framework for the governance } \\
\text { network }\end{array}$ & $\begin{array}{l}\text { Network framing (hands- } \\
\text { off) }\end{array}$ \\
\hline 2018200805 & $\begin{array}{l}\text { Van der Lee } \\
\text { (Greens) } \\
\text { Diks (Greens) }\end{array}$ & $\begin{array}{l}\text {...about the report } \\
\text { "Human rights in wind } \\
\text { supply chains' by } \\
\text { ActionAid and SOMO }\end{array}$ & $\begin{array}{l}6 \text { How do you assure the incorporation of human rights in } \\
\text { wind supply chains in future tenders and permit-requests } \\
\text { for wind-energy and the National Agreement on Energy } \\
\text { and Climate? } \\
7 \text { Are you willing to initlate binding agreements with the } \\
\text { energy-sector, offshore construction and wind turbine } \\
\text { prooducers concerning identification, prevention and } \\
\text { mitigation of environmental and human rights-related } \\
\text { risks, within the current process, or differently? If not, } \\
\text { why? And if so, how are you planning to do so, and vhen } \\
\text { will the parliament be informed on the progress? }\end{array}$ & $\begin{array}{l}\text { Proposals to } \\
\text { determinine what } \\
\text { topics are on the } \\
\text { agenda } \\
\text { Asking for } \\
\text { information on the } \\
\text { govermance } \\
\text { network }\end{array}$ & $\begin{array}{l}\text { The meta-governor sets a } \\
\text { financial, legal or discursive } \\
\text { framework for the governance } \\
\text { network } \\
\text { The meta-governor monitors } \\
\text { the performance of the } \\
\text { network in terms of the } \\
\text { surrounding framework }\end{array}$ & $\begin{array}{l}\text { Network framing (hands- } \\
\text { off) }\end{array}$ \\
\hline 2018200120 & $\begin{array}{l}\text { Snels } \\
\text { (Greens) } \\
\text { Van der Lee } \\
\text { (Greens) }\end{array}$ & $\begin{array}{l}\text {...about the demand of } \\
\text { higher investment- } \\
\text { criteria for loans } \\
\text { regarding fossil } \\
\text { investments }\end{array}$ & 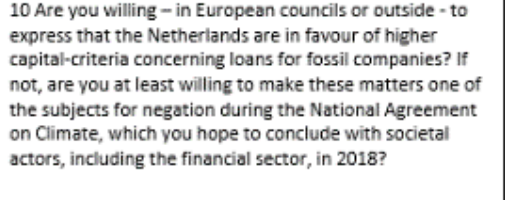 & $\begin{array}{l}\text { Proposals to } \\
\text { determine what } \\
\text { topics are on the } \\
\text { agenda } \\
\text { Proposals regarding } \\
\text { the position of } \\
\text { particular actors } \\
\text { within the network }\end{array}$ & $\begin{array}{l}\text { The meta-governor sets a } \\
\text { financial, legal or discursive } \\
\text { framework for the governance } \\
\text { network }\end{array}$ & $\begin{array}{l}\text { Network framing (hands- } \\
\text { off) } \\
\text { Network management } \\
\text { (hands-on) }\end{array}$ \\
\hline
\end{tabular}

Figure 7. The application of meta-governance strategies by submitted parliamentary questions (2). 


\subsection{Enhancing Democratic Legitimacy of Governance Networks in Sustainability Transitions: What Role for Political Meta-Governance?}

This study examined the democratic legitimacy of network governance in sustainability transitions, applied on the case of the Dutch Agreement on Climate, and studied the role of political meta-governance therein. Accordingly, the study assumed a relationship between the application of political meta-governance and democratic legitimacy of governance networks.

In doing so, we operationalized democratic legitimacy by using a threefold conceptualization as provided by Klijn and Edelenbos [48], further elaborated by Klijn and Koppenjan [10]. This conceptualization consists of the elements that were comprehensively elaborated above; accountability, voice, and due deliberation.

The second, independent variable of this study consisted of the application of political meta-governance. Here, the application of meta-governance strategies as provided by Sørensen and Torfing was used. This conceptualization has been elaborated above, too, and consists of network design, network framing, network management and network participation $[38,42,44]$.

Now let us turn towards the role of political meta-governance in safeguarding the democratic legitimacy in our studied case. To recall, theoretically, high hopes were casted on the role of meta-governance in enhancing democratic legitimacy [44]. Network design, for instance, is argued to potentially safeguard the inclusion of all affected stakeholders and assure publicity concerning the network [44]. Endeavors concerned with network framing may, among others, assure legal, financial and discursive conditions within the operations of the network take place, and enables monitoring and scrutinizing performance therein [44]. Network management is argued to potentially empower weak and marginalized stakeholders and assure transparent and fair circulation of information. In addition, network participation may arguably enhance a broad policy agenda, as the meta-governor engages in day-to-day interaction with the network as a whole [44]. Empirically, this study showed mixed experiences concerning the role for meta-governance in enhancing democratic legitimacy. The preceding sections will interrelate the research findings presented above with one another in order to provide a point of departure for general conclusions.

\subsubsection{Network Design and Assuring the Inclusion of all Affected Stakeholders and Publicity}

Although attempts to apply the meta-governance strategy network design were shown, the governance network itself can be regarded as being relatively exclusive. Indeed, tangible attempts concerning the inclusion of all affected actors (see, e.g., the resolution to include the financial sector and environmental organizations) occurred. Notwithstanding the importance of these attempts, administrative rules concerning the general accessibility of the governance network were applied strictly, demanding negotiating actors to proactively self-organize and impose their presence in the network and resulting in the exclusion of specific societal groups (e.g., fishermen and citizens opposing wind farms were mentioned). A dilemma put forward, here, is that most political and negotiating actors consider the network as being relatively inclusive and generally well balanced. To recall the expression of a policy advisor, he "wouldn't know how to do it better", as there is no "scientifically perfect balance" of whom to include. When holding on to the theoretical conceptualization of voice, however, rules regarding access indicate privileged access, and therefore relative exclusiveness $[48,57]$.

Attempts to apply network design to assure publicity of the network were shown as well, for instance by assuring interfaces with Parliament in advance, and calling upon the executive branch of government to proceed the negotiation in public. However, both political actors and negotiating actors value the transparency of the governance network as "low to zero", but simultaneously "as high as possible", as they both acknowledge that "negotiating in the public is impossible". Accordingly, the application of network design was shown to occur but did not cause significant differences concerning the inclusiveness nor the publicity of the governance network. 


\subsubsection{Network Framing and Assuring and Monitoring a Framework for Network Governance}

Application of the network framing strategy was reported manifold, as elected officials used their position to provide a framework for network governance to be organized. In particular, discursive framing occurred. Nonetheless, the framework, in this case incorporated in the politically endorsed Coalition Agreement, causes actors to be well aware of the strong position of the Dutch Parliament and positively contribute to a formal basis to render account on. Accordingly, this can mainly be regarded as positively influencing the democratic value of accountability, particularly strengthening the existing accountability relationship between the controlling and executive branches of government [63].

\subsubsection{Network Management and Empowering Weaker Stakeholders}

The application of network management as hands-on meta-governance strategy was not reported extensively. Indeed, political actors particularly regard the activities related to network management as tasks for executive government and public administrators [63]. What is more, is that actors that can be considered in a relatively weak (e.g., Greenpeace) position in comparison to private actors put forward that they "would not accept support from government", even if they were offered. Accordingly, no correlation between network management by elected officials and values of democratic legitimacy could be discovered.

\subsubsection{Network Participation and Enhancing a Broad Policy Agenda}

Although Sørensen defines network participation as direct participation, this study reported more indirect ways of network participation. MP's report to, indeed, engage in direct interaction with negotiating actors. However, they do so in the "regular" realms of the Dutch political arena, implicitly indicating they are reluctant to participate in the studied interactive governance arena itself. Although influencing the policy agenda through network participation was mentioned, network participation was shown to be particularly aimed at exchanging information. Indeed, a reciprocal relationship between political and negotiating actors was reported. Political actors used their interaction with actors to obtain information regarding the ongoing negotiations and to address topics they were concerned with, whereas negotiating actors used their interaction to explore the political feasibility and appropriateness of specific measurements and proposals (compare with network framing in Sørensen [26]). Arguably, these pathways of direct communication between political and negotiating actors will "provide valuable inputs to the formulation of new and adequate solutions" and "a strong commitment of the political community" to realize the negotiated policies and secure goal achievement [42].

\section{Conclusions and Discussion}

In this article, we set out to address the manifestation of political leadership as meta-governance, and what consequences this has for democratic legitimacy of network governance in sustainability transitions. We therefore studied a case of national-level interactive climate governance, provided by the Dutch Agreement on Climate ("Nationaal Klimaatakkoord"). Before we present our conclusions, we would first like to address the limitations of our study. First, we have conducted a single case study research which allowed us to do in-depth analysis, but at same time limits us in generalizing our findings and projecting these to countries other than the Netherlands. Furthermore, the particular tradition of interactive climate governance in the Netherlands, as well as the relatively strong nature and position of societal actors, should be taken into account. Moreover, time has been a serious limitation, as the governance process subject to this research was running simultaneously to the process of data gathering. Indeed, no final policy outcomes are to be reported, and consequently, the legitimacy of those outcomes could only be estimated to a limited extent, partly based on expectations of interviewees and the announced process. Despite these limitations we believe we still can draw meaningful conclusions. 
A first conclusion from the case analysis of the Dutch Agreement on Climate underlines the development is that government officials are increasingly seeking to solve complex problems through "interactive forms of governance", such as governance networks [42]. In addition, the state-centered character of the analyzed case on the national agreement on climate shows that state actors retain to play a "pivotal role", even in cases of more horizontality among actors in interactive governance [18]. Accordingly, participating actors indicated to be aware of the close presence and potential interference of governmental actors, illustrating a "shadow of hierarchy" [39,64].

A second conclusion that can be drawn from our case study is that political leaders do not have the full capacities and are not really prepared to perform the roles of meta-governance. We identified that political leaders were able to perform some meta-governance strategies, i.e., network framing and participation, but were not able to encompass all four available strategies, including network design and management. This is in line with previous literature stressing that the role of meta-governance is challenging, and that people need the right capacities to apply fully-fledged meta-governance strategies [52]. This conclusion falls apart in the following arguments. First, Torfing et al. put forward that "the effective and efficient exercise of meta-governance calls for a mix of the different forms" thereof. This study reported the application of disparate meta-governance strategies but does not illustrate such a mixed approach towards complementing hands-off strategies with hands-on strategies and vice versa. Second, the limited application of political meta-governance partly roots in leaving the lions" share of meta-governance strategies to the executive branch of government and public administrators, due to the general conception that these, in particular network design and network management, are administrative roles. Although the role image of political meta-governors was not widely recognized in the studied case, some politicians did take a proactive stance in applying two meta-governance strategies in particular: network framing and network participation. Nonetheless, a deliberate, integrative, and fully-fledged approach towards meta-governing the Dutch Agreement on Climate, covering all different elements of meta-governance as such, did not come about. Barriers concerning the application of political meta-governance by elected officials have been reported manifold, and concern among others:

- Narrow interpretation of meta-governance [44];

- Limited resources [52];

- Political role conflicts [51];

- Democratic tradition and institutions [58].

As can be drawn from the case of the Dutch Agreement on Climate, this study adds to those obstacles:

- $\quad$ Limited time and organizational capacity to meta-govern (compare Vabo \& Røiseland [36]);

- Political priorities concerning the substantive issues that are to be meta-governed.

A third conclusion is that the strong anchorage of interactive governance processes in a broader, politically endorsed governance framework safeguards both democratic accountability and in turn strengthens the ability of political leaders to apply network framing strategies [44]. This conclusion can be explained in two ways: The state-centered character of interactive governance portrayed in this case, being the result of anchoring network governance in governmental policy, safeguards traditional mechanisms of vertical political accountability [10]. Consequently, there is a common sense regarding who is accountable to whom. That is, the minister of Economic Affairs and Climate, representing the executive branch of government, is accountable towards the Dutch Parliament, representing the controlling branch of government. The politically endorsed Coalition Agreement is the formulated basis over which account is rendered. Both in terms of input (determining the framework) and output (final decision-making), hence, the representative position of the Dutch Parliament is safeguarded. In doing so, perhaps the most controversial dimension of governance through governance networks, decision-making by societal actors, is mediated. The ability of politicians to apply network framing 
has been partly fostered by anchorage of network governance in broader governmental policy as well. Here, again, this framework-setting role is not considerably different from the traditional position of representative bodies in the Netherlands [52].

Consequently, this is likely to be regarded as the "government of governance" rather than "governance of governance". The case shows that network framing was shown to be particularly discursive. Indeed, politicians associated discursive network framing with their more traditional agenda-setting role. The broader governance framework provided by the Coalition Agreement has been extensively debated in the Dutch parliamentarian arena, and hence provided space for network framing within the traditional realm of politics. As reported, both formal means in the political arena, such as parliamentary resolutions and questions, as well as informal means, such as informal contacts with actors, were used to this end.

The findings of this study underline that, although some meta-governance strategies do come about, the exercise of meta-governance is generally regarded as a mere task for executive government rather than elected officials. In doing so, the Netherlands appear somewhat comparable with Canada, as both countries show that state-directed administrative meta-governance is dominant [25]. Indeed, this may hold severe implications for democratic legitimacy and the position of elected officials [63]. Accordingly, the pathway towards lasting role innovation concerning the role of elected representatives, has again been shown to be a long and bumpy one. Although the emphasis on elected officials as political meta-governors is arguably a justified one, this study reported a high relevance for administrative meta-governance. Although one may argue that, indeed, the executive branch of government is controlled by elected officials, the tendency to leave meta-governance a mere administrative task comes at a severe risk of damaging democratic values [63]. Nonetheless, based on this study, the divide between political and administrative meta-governance might be considered a redundant one. Accordingly, future research might consider defining political meta-governance broader-that is, including administrative meta-governance.

A fourth conclusion is that, although political accountability is anchored very well, critical remarks can be made concerning the societal and public accountability of the governance network [10]. Although this fits the representative model of democracy very well, in which elected officials are held accountable using political mechanisms of accountability, accountability as elaborated in associative and deliberative models of democracy tends to be underexposed. Indeed, this stresses the importance of the governance network to encounter the broader citizenry [49].

A fifth conclusion that may be drawn from this case study is that values other than democratic accountability, i.e., voice and due deliberation, perform relatively poor in state-centered interactive governance. The focus of political leadership is securing accountability, which goes as the expense of democratic values of voice and deliberation. This particularly relates to two renowned dilemmas regarding network governance. The first dilemma, relating to voice, explicitly addresses the tension between effectiveness and inclusiveness [14]. As they put forward, "the more that organizational participants are involved in the network decision process, the more time consuming and resource intensive that process will tend to be". As the governance process examined in the case of the Dutch Agreement on Climate is confronted with a particular timeframe, choices regarding its composition are made. This, indeed, resulted in the explicit exclusion of particular actors. Generally, this encountered understanding among both political actors and negotiating actors, as long as a certain substantive balance of interests was safeguarded. The second dilemma, relating to due deliberation, has been identified by Torfing et al. and concerns the tension between secluded and transparent governance [62]. As the case of the Dutch National Agreement on Climate shows, this continues to pose dilemmas regarding the degree of transparency that is to be included.

We then would like to conclude with some final words. This study indicated the retaining importance of state actors in network governance in sustainability transitions. The findings of this study, on the other hand, suggest a clearly limited role for political meta-governance in enhancing the democratic performance of governance networks. Consequently, further research into the role of 
political meta-governance in relation to democratic legitimacy is needed. Directions aimed at building forward on the findings reported in this study may aim to examine, among others:

- The democratic legitimacy of administrative meta-governance rather than political meta-governance, and consequences of interactive governance regarding the traditional divide between controlling and executive branches of government;

- The application of meta-governance in (in contrast to national-level) local governance concerned with sustainability transitions on decentered levels of government;

- The democratic legitimacy of sustainability transitions in terms of democratic values other than accountability, due deliberation, and voice, with less emphasis on representative models of democracy;

- The deliberate application of meta-governance strategies by state-centered administrative actors and civil servants, particularly aimed at democratic legitimacy;

- Success factors relating to role innovation of political meta-governors.

It is clear that the current and future importance of sustainability transitions on all levels of government calls for closely studying the way these may best be governed. As this study showed, it is not only problematic for sustainability transitions to overcome particular obstacles concerning their effective implementation, but also concerning their democratic legitimacy. Despite the clear presence of actor-network logic, the political character of sustainability transitions calls for research in sustainability transitions to be well aware of not downplaying the importance of political leadership and the role of elected officials therein. Hence, we call upon future research to closely scrutinize the way sustainability transitions are to be governed when simultaneously accelerating their speed and safeguarding their democratic legitimacy, and what role lies ahead for new forms of political leadership therein.

Author Contributions: M.O. has been concerned with setting up the theoretical framework, research methodology and execution of the study itself. J.E. advised and supervised the research process and co-authored the article.

Funding: This research received no external funding.

Conflicts of Interest: The authors declare no conflict of interest.

\section{References}

1. Christopoulos, S.; Demir, C.; Kull, M. Cross-sectoral coordination for sustainable solutions in Croatia: The (meta) governance of energy efficiency. Energy Policy 2016, 99, 57-87. [CrossRef]

2. Wilson, C.E.; Morrison, T.H.; Everingham, J.-A. Linking the 'meta-governance' imperative to regional governance in resource communities. J. Rural Stud. 2017, 50, 188-197. [CrossRef]

3. Frantzeskaki, N.; Wittmayer, J.; Loorbach, D. The role of partnerships in 'realising' urban sustainability in Rotterdam's city ports area, The Netherlands. J. Clean. Prod. 2014, 65, 406-417. [CrossRef]

4. Loorbach, D.; Frantzeskaki, N.; Lijnis Huffenreuter, R. Transition management: Taking stock from governance experimentation. J. Corp. Citizensh. 2015, 58, 48-66. [CrossRef]

5. Loorbach, D. Transition management for sustainable development: A prescriptive, complexity-based governance framework. Governance 2010, 23, 161-183. [CrossRef]

6. Rotmans, J.; Kemp, R.; Van Asselt, M. More evolution than revolution: Transition management in public policy. Foresight 2001, 3, 15-31. [CrossRef]

7. Chang, R.; Zuo, J.; Zhao, Z.; Soebarto, V.; Zillante, G.; Gan, X. Approaches for transitions towards sustainable development: Status quo and challenges. Sustain. Dev. 2017, 25, 359-371. [CrossRef]

8. Dal Molin, M.; Masella, C. From fragmentation to comprehensiveness in network governance. Public Org. Rev. 2016, 16, 493-508. [CrossRef]

9. Osborne, S.P. The new public governance? Public Manag. Rev. 2006, 8, 377-387. [CrossRef]

10. Klijn, E.; Koppenjan, J. Govenance Networks in the Public Sector; Routledge: New York, NY, USA, 2016.

11. Ansell, C.; Gash, A. Collaborative governance in theory and practice. J. Public Adm. Res. Theory 2008, 18, 543-571. [CrossRef] 
12. Torfing, J. Governance networks. In The Oxford Handbook of Governance; Levi-Faur, D., Ed.; Oxford University Press: Oxford, UK, 2012; pp. 99-113.

13. Mayer, I.; Edelenbos, J.; Monnikhof, R. Interactive policy development: Undermining or sustaining democracy? Public Adm. 2005, 83, 179-199. [CrossRef]

14. Provan, K.G.; Kenis, P. Modes of network governance: Structure, management, and effectiveness. J. Public Adm. Res. Theory 2008, 18, 229-252. [CrossRef]

15. Rhodes, R. The new governance: Governing without government. Political Stud. 1996, 44, 652-667. [CrossRef]

16. Rutherford, J.; Coutard, O. Urban energy transitions: Places, processes and politics of socio-technical change. Urban Stud. 2014, 51, 1353-1377. [CrossRef]

17. Hendriks, C.M. Policy design without democracy? Making democratic sense of transition management. Policy Sci. 2009, 42, 341. [CrossRef]

18. Bell, S.; Hindmoor, A. The governance of public affairs. J. Public Aff. 2009, 9, 149-159. [CrossRef]

19. Haveri, A.; Nyholm, I.; Røiseland, A.; Vabo, I. Governing collaboration: Practices of meta-governance in finnish and norwegian local governments. Local Gov. Stud. 2009, 35, 539-556. [CrossRef]

20. Jessop, B. The rise of governance and the risks of failure: The case of economic development. Int. Soc. Sci. J. 1998, 50, 29-45. [CrossRef]

21. Kooiman, J.; Jentoft, S. Meta-governance: Values, norms and principles, and the making of hard choices. Public Adm. 2009, 87, 818-836. [CrossRef]

22. Head, B.W. Evidence, uncertainty, and wicked problems in climate change decision making in Australia. Environ. Plan. C Gov. Policy 2014, 32, 663-679. [CrossRef]

23. Avelino, F.; Wittmayer, J. Shifting power relations in sustainability transitions: A multi-actor perspective. J. Environ. Policy Plan. 2016, 18, 628-649. [CrossRef]

24. Avelino, F.; Grin, J.; Pel, B.; Jhagroe, S. The politics of sustainability transitions. J. Environ. Policy Plan. 2016, 18, 557-567. [CrossRef]

25. Doberstein, C. Metagovernance of urban governance networks in Canada: In pursuit of legitimacy and accountability. Can. Public Adm. 2013, 56, 584-609. [CrossRef]

26. Sørensen, E. Institutionalizing interactive governance for democracy. Crit. Policy Stud. 2013, 7, 72-86. [CrossRef]

27. Klijn, E.; Skelcher, C. Democracy and governance networks: Compatible or not? Public Adm. 2007, 85, 587-608. [CrossRef]

28. Jagroe, S. Urban transition management as a democratic practice? The case of Rotterdam's waterfront regeneration. In Co-Creating Sustainable Urban Futures: A Primer on Applying Transition Management in Cities; Frantzeskaki, N., Hölscher, K., Wittmayer, J., Avelino, F., Bach, M., Eds.; Springer International Publishing: Cham, Switzerland, 2018; pp. 349-371.

29. Meadowcroft, J. What about the politics? Sustainable development, transition management, and long term energy transitions. Policy Sci. 2009, 42, 323-340. [CrossRef]

30. Klijn, E.; van Buuren, A.; Edelenbos, J. The impact of governance: A normative and empirical discussion. In The Oxford Handbook of Governance; Levi-Faur, D., Ed.; Oxford University Press: Oxford, UK, 2012; p. 294.

31. Teisman, G.R. Models for research into decision-MakingProcesses: On phases, streams and decision-making rounds. Public Adm. 2000, 78, 937-956. [CrossRef]

32. Levi-Faur, D. The Oxford Handbook of Governance; Oxford University Press: Oxford, UK, 2012.

33. Baker, K.; Stoker, G. Metagovernance and nuclear power in Europe. J. Eur. Public Policy 2012, 19, 1026-1051. [CrossRef]

34. Khan, J. What role for network governance in urban low carbon transitions? J. Clean. Prod. 2013, 50, 133-139. [CrossRef]

35. Lange, M.; O’Hagan, A.M.; Devoy, R.R.N.; Le Tissier, M.; Cummins, V. Governance barriers to sustainable energy transitions-Assessing ireland's capacity towards marine energy futures. Energy Policy 2018, 113, 623-632. [CrossRef]

36. Vabo, S.I.; Røiseland, A. Conceptualizing the tools of government in urban network governance. Int. J. Public Adm. 2012, 35, 934-946. [CrossRef]

37. Hölscher, K. So what? Transition management as a transformative approach to support governance capacities in cities. In Co-Creating Sustainable Urban Futures; Wittmayer, J., Frantzeskaki, N., Avelino, F., Hölscher, K., Bach, M., Eds.; Springer International Publishing: Cham, Switzerland, 2018; p. 375.

38. Sørensen, E. Metagovernance-The changing role of politicians in processes of democratic governance. Am. Rev. Public Adm. 2006, 36, 98-114. [CrossRef]

39. Whitehead, M. 'In the shadow of hierarchy': Meta-governance, policy reform and urban regeneration in the west midlands. Area 2003, 35, 6-14. [CrossRef] 
40. Van Buuren, A.; Loorbach, D. Policy innovation in isolation? Public Manag. Rev. 2009, 11, 375-392. [CrossRef]

41. Papadopoulos, Y. Interactive governance: Authorization, representation and accountability. In Critical Reflections on Interactive Governance: Self Organization and Participation in Public Governance; Edelenbos, J., van Meerkerk, I., Eds.; Edward Elgar Publishing: Cheltenham, UK, 2016; p. 146.

42. Sørensen, E.; Torfing, J. Theories of Democratic Network Governance; Palgrave Macmillan UK: London, UK, 2016.

43. Brown, R.R.; Farrelly, M.A.; Loorbach, D.A. Actors working the institutions in sustainability transitions: The case of melbourne's stormwater management. Glob. Environ. Chang. 2013, 23, 701-718. [CrossRef]

44. Sørensen, E.; Torfing, J. Making governance networks effective and democratic through metagovernance. Public Adm. 2009, 87, 234-258. [CrossRef]

45. Papadopoulos, Y. Cooperative forms of governance: Problems of democratic accountability in complex environments. Eur. J. Political Res. 2003, 42, 473-501. [CrossRef]

46. Matthews, F. Governance and state capacity. In The Oxford Handbook of Governance; Levi-Faur, D., Ed.; Oxford University Press: Oxford, UK, 2012; p. 281.

47. Avelino, F. Power in sustainability transitions: Analysing power and (dis)empowerment in transformative change. Environ. Policy Gov. 2017, 27, 505-520. [CrossRef]

48. Klijn, E.H.; Edelenbos, J. The influence of democratic legitimacy on outcomes in governance networks. Adm. Soc. 2013, 45, 627-650. [CrossRef]

49. Aarsæther, N.; Bjørnå, H.; Fotel, T.; Sørensen, E. Evaluating the democratic accountability of governance networks: Analysing two nordic megaprojects. Local Gov. Stud. 2009, 35, 577-594. [CrossRef]

50. Meadowcroft, J. Engaging with the politics of sustainability transitions. Environ. Innov. Soc. Transit. 2011, 1, 70-75. [CrossRef]

51. Edelenbos, J.; van Meerkerk, I.; Koppenjan, J. The challenge of innovating politics in community self-organization: The case of broekpolder. Public Manag. Rev. 2017, 19, 55-73. [CrossRef]

52. Koppenjan, J.; Kars, M.; van der Voort, H. Politicians as Metagovernors-Can Metagovernance Reconcile Representative Democracy and Network Reality? ECPR Press: Colchester, UK, 2011; p. 148.

53. Torfing, J.; Peters, G.; Pierre, J.; Sørensen, E. Power and politics in interactive governance. In Interactive Governance: Advancing the Paradigm; Torfing, J., Peters, G., Pierre, J., Sørensen, E., Eds.; Oxford University Press: Oxford, UK, 2013.

54. Levin, K.; Cashore, B.; Bernstein, S.; Auld, G. Overcoming the tragedy of super wicked problems: Constraining our future selves to ameliorate global climate change. Policy Sci. 2012, 45, 123-152. [CrossRef]

55. Damgaard, B.; Torfing, J. The impact of metagovernance on local governance networks. Lessons from danish employment policy. Local Gov. Stud. 2011, 37, 291-316. [CrossRef]

56. Christopoulos, S.; Horvath, B.; Kull, M. Advancing the governance of cross-sectoral policies for sustainabble development: A metagovernance perspective. Public Adm. Dev. 2012, 32, 305-323. [CrossRef]

57. Daugbjerg, C.; Fawcett, P. Metagovernance, network structure, and legitimacy: Developing a heuristic for comparative governance analysis. Adm. Soc. 2017, 49, 1223-1245. [CrossRef]

58. Fotel, T.; Hanssen, G.S. Meta-governance of regional governance networks in Nordic countries. Local Gov. Stud. 2009, 35, 557-576. [CrossRef]

59. Torfing, J.; Peters, G.; Pierre, J.; Sørensen, E. New roles and role dilemmas in interactive governance. In Interactive Governance: Advancing the Paradigm; Torfing, J., Peters, G., Pierre, J., Sørensen, E., Eds.; Oxford University Press: Oxford, UK, 2013.

60. Yin, R.K. The case study as a serious research strategy. Knowledge 1981, 3, 97-114. [CrossRef]

61. Eisenhardt, K.M. Building theories from case study research. Acad. Manag. Rev. 1989, 14, 532-550. [CrossRef]

62. Torfing, J.; Peters, G.; Pierre, J.; Sorensen, E. Transparency and governance. In Interactive Governance: Advancing a Paradigm; Oxford University Press: Oxford, UK, 2013; p. 208.

63. Torfing, J.; Pierre, J.; Peters, G.; Sorensen, E. Assessing and improving the democratic quality of interactive governance. In Interactive Governance: Advancing a Paradigm; Oxford University Press: Oxford, UK, 2013; p. 186.

64. Nederhand, J.; Bekkers, V.; Voorberg, W. Self-organization and the role of government how and why does self-organization evolve in the shadow of hierarchy? Public Manag. Rev. 2016, 18, 1063-1084. [CrossRef]

(C) 2018 by the authors. Licensee MDPI, Basel, Switzerland. This article is an open access article distributed under the terms and conditions of the Creative Commons Attribution (CC BY) license (http:/ / creativecommons.org/licenses/by/4.0/). 